\title{
Assessing the English Language Needs of Observers and Staff Officers: With Special Reference to Amhara Police College Peacekeeping English Project, Amhara Regional State, Ethiopia
}

\author{
Wubliker Ephrem Yigzaw \\ Department of English Language and Literature, Debre Markos University, Ethiopia
}

\begin{abstract}
The main concern of this study was to assess the English language needs of the staff officers and observers with particular reference to Amhara police college peacekeeping English project. Regarding to this, special attention has been given to specifying the Basic English language needs and sub-skills of language items and various English language activities that could meet the specific language needs of trainees who are going to be participated in the UN peacekeeping mission areas. From the point of research design, descriptive survey type (non-experimental) research design was used to study attitudes, opinions and characteristics of a particular individual, situation or group. To achieve the goal of this study, questionnaire was used as a major data gathering tool. Thus, questionnaire was designed and distributed to twenty staff officers and observers who are only police. All the participants of this study have served in the mission areas and they are currently working in police commission Bureau, Police College and in each zonal police offices. On the other hand, interview was also conducted with eight staff officers and observers to cross check the data gained through the questionnaire. Since the subjects are a few in numbers (20), the study used purposive sampling technique. Besides, the study has also analyzed the current course books which are currently delivered to the trainees. These course book materials are campaign English for the military from level 1-3 and English for law enforcement which is especially designed for the police. The data gathered through questionnaire was analyzed using descriptive statistical solutions such as percentage, mean, standard deviation. With the same regard, the data collected through interview and text analysis were analyzed qualitatively. The findings of the study indicated that speaking, writing and listening are the most frequently needed language skills for the observers and staff officers in order to discharge the duties and responsibilities in the UN peacekeeping mission areas. Among the frequently needed micro languages are listening to instructions given by officers in charge of various tasks, listening to foreign contingents and local communities, reading e-mails, reading notices, schedules, writing daily occurrence reports, writing shift log, speaking on the telephone and presenting oral reports are the major ones. Furthermore, the study clearly disclosed that the staff officer and observers have got some English language difficulties like listening to briefings, discussions, listening to meetings, seminars, conference and workshop, presenting oral report, giving briefings, giving press conference, writing investigation report, writing patrol report and writing scene of crime. With regard to the text books, the study clearly showed that the materials are generally designed in such good way. But there are some points which are missed in the text books. For example, they do not comprise topics and contexts especially in relation to Africa. In addition there is a gap between the text books and what is actually happening in the mission areas for the trainees.
\end{abstract}

Keywords: staff officers, observers, Amhara police college, peacekeeping, English for specific purposes (ESP) DOI: $10.7176 /$ RHSS/10-21-04

Publication date: November $30^{\text {th }} 2020$

\section{CHAPTER ONE: INTRODUCTION}

\subsection{Background of the study}

The demand for peacekeeping throughout the world continues to increase. As it is clearly showed, after the end of cold war the need of peacekeepers, have been increasing in an immense way. In recent years the need has increased by $400 \%$. According to United Nations (UN) data, 10,000 peacekeepers were deployed in different parts of the world in 1993. By 1998 that figure had increased to 80,000 and as of April 2017 it stands at 96, 865, and showed a slight decrease from 2015. Thus, these figures already denote that the demand for peacekeepers' has increased steadily (English Language Training Policy, 2017).

Ethiopia is located in one of the most conflict prone areas of the globe and has a history of contributing to UN peacekeeping missions. Since its first participation in Korea in the 1950s, Ethiopia has deployed troops and police on peace support missions in the Congo, Rwanda and Burundi. Currently it contributes to UN missions in Darfur, Abyei, South Sudan, Haiti and Mali, and in April 2017 was the largest contributor with 8,342 personnel, of whom 67 were police, 101 military experts and 8,174 Troops. It also has the highest number of female peacekeepers, 642. Ethiopia also contributes to the African union (AU) mission to Somalia, which brings its contribution to above 11,000. Its continuing commitment to both $\mathrm{UN}$ and $\mathrm{AU}$, peacekeeping is demonstrated by the governments' peace support training center which is becoming a center of excellence, meeting the highest standard and working towards regional and continental cooperation (Ethiopian Ministry of National Defense 
English language training policy, 2017).

Now days, the police forces and troops are participating in humanitarian assistance as well as in peacekeeping operations under auspices of the United Nations (UN), European Union (EU) or African Union (AU). Countries which have been contributing for peacekeeping missions either police forces or military contingents or individual police are under the control of a central command or head quarters. The Ethiopian ministry of national defense (EMoND) and the Ethiopian federal police commission (EFPC) recognize that in order to carry out the peacekeeping responsibilities effectively, it is essential for Ethiopian peacekeepers to be able to communicate in English to internationally recognized standards as English is the lingua franca of most missions. In line with this, need intensive training in peacekeeping related English has become mandatory (English language training policy, 2012).

Furthermore, the EMoND language training program was established in July 2008 under the auspices of the Human resources and development department. In April 2009 responsibility for the program was transferred to the then peacekeeping training center now the peace support training center. And the EFPC program was established in November 2013 though there had been some training delivered on their behalf by the EMoND. Thus, taking this responsibility lies with the peacekeeping department at the police head quarters. As it is known, English is the operational language of this mission. It is very expected and mandatory that any police member has to talk to each other and communicate in English which is the official language. In addition, peacekeeping troops will frequently need to liaise with non-governmental organizations that are operating in the mission area which makes the need to have good command of the English language mandatory.

Both programs: EMoND and EFPC language training program receive substantial support from the United Kingdom (UK) peacekeeping English project (PEP). The PEP is funded by the UK government's conflict security stabilization fund; prior to April 2015 it was funded by the African conflict prevention pool. As with the over 40 similar projects that existed since the mid 1990s, the Ethiopian PEP is managed by the British council. The project was set up with an intended duration of five years with the aim establishing a sustainable system of English language training. It has a UK recruited country manager and (2009-2012) a teacher trainer. Therefore, PEP has helped establish seven EMoND and five EFPC language centers, each with equipment and resources for language teaching and learning (including self-access centers), designed a standardized syllabus based on military English and English for law enforcement for peacekeeping missions.

On the basis of the above information, Amhara police college peacekeeping English project (APCPEP) is the one among the other four EFPC projects: Tigray, Oromiya, and south nations, nationalities and people which are aided by UK peacekeeping English project. APCPEP was established in November 2014. Its main objective is to equip Amhara police members, who are expected to participate in the international peacekeeping missions with English language skills such as speaking, listening, writing, reading and other sub skills like vocabulary, grammar and pronunciation. Therefore, its main purpose is to provide high quality English language training to individual students and groups of military and police personnel, and to help those students achieve their English language goals. Besides, it aims at helping would be peacekeepers tackle their English language problem so that they can communicate without difficulty.

\subsection{Statements of the Problem}

Most of the Ethiopian police who have been participating in the international peacekeeping missions seemed to have a critical language problem. They cannot communicate easily in English with other deployed troops since it is an operational and occupational language in the mission areas. Therefore, this implies that they need to have good command of the English language specifically they need to have good language ability in English for Specific Purpose (ESP). We live in the era of globalization, in which people coming from all parts of the world need to exchange and share information on a daily basis. Therefore, it is possible to say that all peacekeepers are from different parts of the world that they need one communicative language which is English. The militaries and police personnel's are using English as English for occupational purpose (EOP). According to Evans and St. John (1998, 5-6) they stated that this EOP is under in ESP.

Having considered the above problem, the UK peacekeeping English project has been working with the EMoND and EFPC since 2008 so as to improve the Ethiopian militaries and police English language proficiency while they are going to be deployed in the mission areas. In line with this, most of the Amhara police trainees have been sent for peacekeeping mission after completing the course. There is a course which has been given for the trainees by dividing them in levels: from level 1-3. During their stay in this course, they are expected to be able to improve their English language skills as well. In the mission areas, they have served as staff officers and observers. The researcher met some of the staff officers and observers and talked to them related to the language. They informed him that they faced various problems with regard to the language. As it is known, in peacekeeping mission areas people are from different parts of the world. Therefore, the language that is need for communication is English. Most of the deployed troops are either second language speakers of English or natives, but in Ethiopian cases it is used as foreign language speakers. Because of this, most of Ethiopian troops are facing communication 
problems in the mission areas. Thus, something must be done to alleviate these problems.

On the other hand, the researcher has tried to see other related researches done by others. However, most of the researches have been done are based on ESP specifically on English for Academic purpose (EAP). For example, Belachew (2008) conducted a research on language need analysis of construction trainees at TVET College and this implies that the work more or less concentrated on English for General Academic purpose (EGAP) though it is ESP in wider context. Furthermore, Haile (2015) also conducted a research on determining the English language needs of Law students designing English for Legal Academic purpose (ELAP) syllabus. Moreover, some others also conducted researches on similar issues like Abiy (1989) on communicative needs of students of Ethiopian high schools, Hailemichael (1993) on communicative needs of Ethiopian university students, Molla (2006) on communicative needs of Law students. Therefore, all these researches do have relations one another since they share something in common i.e. they all are studies on ESP.

With this regard, the researcher believed that he had to search other more related research done by others because all the researches mentioned above are EAP even if they are ESP and they share the same thing with this research. But the current research relies especially on EOP. Therefore, Girum (2014) conducted a research on language need assessment of militaries especially at the Air force in Debre Zeit. However, his research has covered only the militaries who are assigned in different sections of UN peacekeeping mission areas. It did not include the law enforcement officials or police officers. As it is known police officers and militaries do have quite different works in the mission areas. Taking this fact in to account, this study was aimed at assessing the English language needs of staff officers and observers of police only. To that end, needs analysis was indispensable. Hutchinson and Walter (2006) argue that realizing why the learners need English will have an influence on what will be acceptable as reasonable content in the language course and on the positive side, what potential can be exploited.

Thus, what makes the present study different from other similar studies is that as to the knowledge of the researcher it is the only study locally conducted on analyzing the English language needs of observers and staff officers.

\subsection{Objectives of the study}

\subsubsection{General objective}

The main objective of this study was to assess the English language needs of the staff officers and observers who participated in the mission areas.

\subsubsection{Specific objectives}

The specific objectives were to:

1. Identify the English language skills that the staff officers and observers have problems with.

2. Identify the staff officers' and observers' English language skills that they need to develop

3. Assess whether or not the current English course books address the English language needs of staff officers and observers.

\subsection{Research questions of the study}

The study pays attention to the language needs of police observers and staff officers. Therefore, it has tried to answer the following research questions:

1. Which language skills do the staff officers and observers have problems with?

2. Which language skills do the staff officers and observers need to develop?

3. Do the current course books meet the English language needs of staff officers and observers?

\subsection{Significance of the study}

The researcher believes that the result of this study provides information for those who have a direct or indirect relation of this study. As a result, the study can have the following contributions:

1. It would stimulate the staff officers and observers to take English courses which enable them to achieve their goal successfully.

2. It can also serve as a source for this project. Thus, English course designers and instructors will identify the English language needs of their trainees and prepare materials and tasks accordingly.

3. It can be used as an input for those who are interested to conduct further study on the issue.

\subsection{Scope of the Study}

There are eleven peacekeeping English project centers in Ethiopia. Among these four of them are federal police and the rest seven are EMoND. To keep the study manageable, this study focuses on one of Federal police centers located in Debre Markos under Amhara police college peacekeeping English project center. It is also delimited to the assessment of English language needs of staff officers and observers since the researcher is the teacher of this project. 


\subsection{Limitations of the Study}

This study has got some constraints. Primarily, it is worth keeping in mind that the sample size of the study was limited to only 20 respondents of observers and staff officers of Law Enforcement officials in the UN peacekeeping mission areas. Since the numbers of respondents are limited, it could create danger to make generalization of the study as a whole. Furthermore, this study did not see the confounding effects of variables how one variable affects another one in the interrelated manner.

\section{CHAPTER THREE: METHODOLOGY AND PROCEDURES}

This chapter encompasses the research methodology which focuses on the description of research methods and data gathering tools. It also presents the research design, subjects, sampling technique, sample size and techniques of data analysis.

\subsection{Research Design}

In this research, descriptive survey type (non-experimental) research design was used. Descriptive research design was selected for it is particularly well suited to studying attitudes, opinions and characteristics of a particular individual, situation or group. Descriptive study is also a means of discovering new meaning, describing what exists, determining the frequency with which something occurs and categorizing information (Natasha and Cynthia, 2005).

\subsection{Research Setting}

The research setting area of this study was Amhara police college peacekeeping English project centre. This project centre is selected deliberately because of the fact that the problems mentioned in the statements of the problem section are observed and its accessibility regarding to proximity of the researcher. With this regard, Amhara Police College is located in Debre Markos which is 300 kilo meters far from the capital city, Addis Ababa.

\subsection{Participants of the Study}

The populations of the study or subjects are staff officers, observers and liaison officers who are returned from mission areas. The staff officers and observers were the ones who were believed to provide first hand, necessary and relevant information about the target situation of English language needs. This is because they know what has been actually happening in the mission areas since they got the opportunity to realize the language skills needed so as to fulfill their duties and responsibilities. Since they had realized the whole thing in the mission areas, they can provide primary source of data for the researcher as well. Therefore, it can be said that the returnees are able to give information about the challenges faced by Ethiopian staff officers and observers with regard to their language proficiency while they were deployed in the mission areas.

\subsection{Sampling Technique}

Comprehensive sampling technique was used in the questionnaire to include all staff officers and observers returnees and to get sufficient information from them. In addition, gathering essential information in an immense quantity for a certain research is time taking because valid conclusion can often be drawn from a relatively small amount of data. Therefore, this study tried to encompass only staff officers and observers for the sake of getting relevant information and it is also limited on those who are only returned from the mission. Thus, sampling is a means to select representatives of the population in a systematic manner.

In this study, the following sample populations from Amhara police college peacekeeping English project were included police personnel who had participated in the peacekeeping mission areas as observers, staff officers returned home and currently working at Amhara Police College and Amhara police commission and each zonal police offices. Therefore, the researcher used comprehensive sampling technique to select participants of the study for the study requires to selecting for those participants who returned from peacekeeping mission.

\subsection{Sample Size}

The number of returnees who served as staff officers and observers who are currently working at Amhara Police College, Amhara police commission bureau and in each zonal police office are samples of this study. In total, they are about twenty. With this regard, the researcher tried to contact all of them (about 100\%). Therefore, they all were included in the study through the way of purposive sampling technique since as the number of respondents was manageable.

\subsection{Data Gathering Tools}

Research instrument is a device used by researcher to collect relevant data for the study. Thus, to get relevant information from the subjects, the researcher employed three data gathering tools: questionnaire, interview and text analysis. 


\subsubsection{Questionnaire}

Questionnaire is the most widely used data gathering instrument to obtain information from participants. It is useful in order to collect large amount of data in limited time from large number of participants. It is selected since it is thought that it would serve as a means of eliciting the experiences, beliefs, perceptions and attitudes of observers and staff officers regarding the English language needs of them. It is also selected as a means of data collecting tool since it is most frequently used and a very concise preplanned set of questions designed to yield specific information to meet a particular need for research information about the pertinent topic under discussion. Moreover, questionnaire has the following advantages economy, uniformity of questions and standardizations. And expense and time involved in training the interviewers can be reduced by using questionnaire. Besides, each respondent receives the same set of questions which leads to standardizations.

In this study, the close-ended questionnaire was employed. However, an opportunity was given for the respondents to give their answers as they wish by including some open-ended items. The questions focus on three basic areas: the language skills that the staff officers and observers have problems with, language skills and sub skills observers and staff officers need to develop, and the English language skill course taken by observers and staff officers along with their needs. The questionnaire was adapted from Girum (2014) because the researcher believed they help in achieving the intended objectives as they were tested out earlier. The close- ended question items were developed in Likert scale type. In attempt to increase face validity of the items in the questionnaire, advisor's comments and expert judgments were used. Based on the comments gained, some modifications were made in the instructions given and some items were discarded.

\subsubsection{Interview}

In an attempt to collect profound information for the study, the researcher used semi-structured interview to gain the required data about the language needs of observers and staff officers. It would be helpful if the researcher used qualitative data of interview in order to cross-check with that of questionnaire which has already the same sense. As a result, the content of the interview was the same as that of the observers and staff officers. Thus, the contents were prepared based on the four macro and micro skills of language like which language skill have problems with, level of difficulties of these four basic and sub-skills, and the English language skill courses that the staff officers and observers need to develop. Furthermore, semi-structured interview can be conducted in a systematic and consistent order so as to get the relevant information from the interviewees but not digress from the objectives of the study as Berg (1989:17) cited in Tigist (2012). With the same context, all the questions were prepared in the standardized manner by considering other related research works like Girum (2014). The interviews were prepared by the researcher himself, it was commented by the advisor and revised before it was conducted. The interviews took place in face- to -face situation with the participants in their workplace area after data were collected from the questionnaire.

\subsubsection{Text analysis}

The English text books: campaign English for the military from level 1-3 and English for law enforcement which are currently being used were analyzed to see whether or not they met the staff officers and observers English language needs for their professional purposes. Actually, the police officers have been taking the course by giving more attention for law enforcement books because the book is prepared only for police. However, they are also taking some parts of military books of the lesson as supplementary material. Since the course is designed for specific purpose especially to equip the staff officers and observers in occupation aim, it is possible to say that this is all automatically ESP. Therefore, ESP text evaluation checklist prepared by Cunnings Worth (1995) and Donovan and Little John (1998) was used. The text books were analyzed based on these scholars specification measurement since it is very universal to evaluate any text.

\subsection{Data Collection procedures}

In this study the data collection instruments namely questionnaire and interview were designed and employed respectively. It was also employed the text analysis part following the questionnaire and interview conducted with observers and staff officers who were returnees from the UN peacekeeping mission areas.

First of all, this study used questionnaire first because of some reasons: the way it can address the whole respondents easily, it can be administered and distributed easily by the researcher since the respondents are only 20 and it is not time taking that much.

Next, the interview was employed between the researcher and selected 8 respondents of observers and staff officers. This could help for the study to cross check the information with the questionnaire already employed from the beginning. Thus, it can also improve the reliability of data which was employed from the questionnaire.

Finally, text analysis was conducted on considering the teaching course book materials: campaign English for military 1-3 and Law Enforcement book. Actually, this study concentrated on the law enforcement officials. Therefore, intentions more or less relied on the Law Enforcement book which is delivered only for police. 


\subsection{Methods of Data Analysis}

In data analysis, a mixed method approach employing both quantitative and qualitative techniques was used. The quantitative analysis was aided by descriptive statistics such as percentage, mean, standard deviation, from the questionnaire. Besides the data obtained through interview and text analysis part were first transcribed and were analyzed thematically using detail description ways of qualitative data method in order to arrive at sound conclusion. Moreover, the text analysis part was done based on the evaluation checklist.

\section{CHAPTER FOUR: Data presentation, Analysis and Discussion of the Study}

In this chapter, data were presented, analyzed and discussed so as to achieve the objectives of the study and seek answers to the research questions asked already in the first chapter. Therefore, this chapter deals with the data presentation and interpretation of the whole information gathered through questionnaire, interview and text analysis.

Thus, the data gathered through questionnaire was analyzed quantitatively using descriptive statistics such as percentage, mean, standard deviation where as data collected through interview was analyzed qualitatively in thematic analysis to cross check the results obtained from the questionnaire. However, the text analysis part was done by using a checklist which was already adapted from Cunningworth (1995) and Donovan and little john (1998).

\subsection{Analysis of the questionnaire}

This part dealt with the observers and staff officers' English language needs which are employed in the mission areas and language level difficulties as well.

\subsubsection{Analysis of the English language needs of observers and staff officers}

This topic presents about the needs of English language skills of observers and staff officers in the mission areas. Thus, it comprises how often the observers and staff officers needed to do the four basic skill activities: listening, reading, speaking and writing.

There are different activities listed under listening, reading, speaking and writing. Therefore, the respondents were asked to rate how often the needs to do different activities listed under each language skill and sub-skills based on the given scales: 'Always',' usually', 'sometimes', 'rarely' and 'never'. With this regard, the indication of given data under 'always 'and 'usually' were taken as how much those activities were very needed in the mission areas by the observers and staff officers.

\subsection{Responses of Observers and Staff officers regarding to the language Needs (Listening)}

\begin{tabular}{|c|c|c|c|c|c|c|c|c|c|c|c|c|c|}
\hline \multirow[t]{3}{*}{ No } & \multirow[t]{3}{*}{ Listening activities } & \multicolumn{12}{|c|}{ Response } \\
\hline & & \multicolumn{2}{|c|}{ Always } & \multicolumn{2}{|c|}{ Usually } & \multicolumn{2}{|c|}{ Sometimes } & \multicolumn{2}{|c|}{ Rarely } & \multicolumn{2}{|c|}{ Never } & \multirow[t]{2}{*}{ Mean } & \multirow[t]{2}{*}{ SD } \\
\hline & & $\mathrm{F}$ & $\%$ & $\mathrm{~F}$ & $\%$ & $\mathrm{~F}$ & $\%$ & $\mathrm{~F}$ & $\%$ & $\mathrm{~F}$ & $\%$ & & \\
\hline 1 & $\begin{array}{l}\text { Listening to meetings, } \\
\text { seminars, conferences and } \\
\text { workshops }\end{array}$ & 1 & 5.0 & 1 & 5.0 & 14 & 70.0 & 3 & 15.0 & 1 & 5.0 & 2.90 & 0.79 \\
\hline 2 & Listening to videos /films & 1 & 5.0 & 2 & 10.0 & 5 & 25.0 & 10 & 50.0 & 2 & 10.0 & 2.50 & 1.00 \\
\hline 3 & $\begin{array}{l}\text { Listening to } \\
\text { instructions given } \\
\text { by officers in charge of } \\
\text { various tasks }\end{array}$ & 11 & 55.0 & 8 & 40.0 & 1 & 5.0 & 0 & 0.0 & 0 & 0.0 & 4.50 & 0.61 \\
\hline 4 & $\begin{array}{llr}\text { Listening } & \text { to } & \text { foreign } \\
\text { contingent } & \text { and } & \text { local } \\
\text { communities } & & \\
\end{array}$ & 9 & 45.0 & 10 & 50.0 & 1 & 5.0 & 0 & 0.0 & 0 & 0.0 & 4.40 & 0.60 \\
\hline 5 & $\begin{array}{l}\text { Listening to radio } \\
\text { communication }\end{array}$ & 9 & 45.0 & 5 & 25.0 & 3 & 15.0 & 2 & 10.0 & 1 & 5.0 & 3.95 & 1.23 \\
\hline 6 & $\begin{array}{l}\text { Listening to television } \\
\text { /radio }\end{array}$ & 1 & 5.0 & 2 & 10.0 & 6 & 30.0 & 8 & 40.0 & 3 & 15.0 & 2.50 & 1.05 \\
\hline & & & & & & & stening & skill & total $n$ & ean & score & 3.46 & 0.72 \\
\hline
\end{tabular}

Table 4.1 denotes the frequency level of listening activities elicited in different situations. According to this table, the most frequently needed listening activity was listening to instructions given by officers in charge of various tasks. And this activity was reported by $55 \%$ of the observers and the staff officers as frequently needed activity. Besides, the respondents replied that the two activities: listening to foreign contingents and local communities and listening to radio communication do have equal value which was favored by $45 \%$ for each.

Listening to meetings, seminars, conferences and workshops (5\%), listening to videos /films $(5 \%)$ and listening to television /radio (5\%) have got similar value according to the respondents while in the mission areas. Therefore, from these data findings, it can be concluded that the most frequently needed activities for the observers 
and staff officers in mission area is listening to instructions given by officers in charge of various tasks for the sake of accomplishing tasks effectively given by other officers. Furthermore, listening to foreign contingents and local communities is also the frequently activity needed by them.

With the same regard, as it can be seen from the data, the mean value of the most frequent activity was 4.5 and the following activity was 4.4, respectively. These figures show that the tendency how often these two activities are needed while the observers and staff officers were in the UN mission areas. The standard deviation was also mostly less than one for these two main activities. Therefore, this result shows that the deviation from mean was not that much far. In addition, the total grand mean 3.46 and total standard deviation 0.72 showed that the whole listed listening activities are needed to accomplish the tasks in the mission areas.

Table 4.2 Responses of Observers and Staff Officers regarding to the English Needs (Reading)

\begin{tabular}{|c|c|c|c|c|c|c|c|c|c|c|c|c|c|}
\hline \multirow[t]{3}{*}{ No } & \multirow[t]{3}{*}{ Reading activities } & \multicolumn{12}{|c|}{ Response } \\
\hline & & \multicolumn{2}{|c|}{ Always } & \multicolumn{2}{|c|}{ Usually } & \multicolumn{2}{|c|}{ Sometimes } & \multicolumn{2}{|c|}{ Rarely } & \multicolumn{2}{|c|}{ Never } & \multirow[t]{2}{*}{ Mean } & \multirow[t]{2}{*}{ SD } \\
\hline & & $\mathrm{F}$ & $\%$ & $\mathrm{~F}$ & $\%$ & $\mathrm{~F}$ & $\%$ & $\mathrm{~F}$ & $\%$ & $\mathrm{~F}$ & $\%$ & & \\
\hline 1 & $\begin{array}{l}\text { Reading articles, } \\
\text { newspapers, magazines, } \\
\text { journals on police and } \\
\text { social topics }\end{array}$ & 3 & 15.0 & 5 & 25.0 & 3 & 15.0 & 7 & 35.0 & 2 & 10.0 & 3.00 & 1.298 \\
\hline 2 & $\begin{array}{l}\text { Reading } \\
\text { manuals/statements }\end{array}$ & 2 & 10.0 & 6 & 30.0 & 6 & 30.0 & 4 & 20.0 & 2 & 10.0 & 3.10 & 1.165 \\
\hline 3 & Reading reports & 4 & 20.0 & 10 & 50.0 & 3 & 15.0 & 2 & 10.0 & 1 & 5.0 & 3.70 & 1.081 \\
\hline 4 & $\begin{array}{l}\text { Reading rules and } \\
\text { regulations of UN and } \mathrm{AU}\end{array}$ & 4 & 20.0 & 6 & 30.0 & 9 & 45.0 & 1 & 5.0 & 0 & 0.0 & 3.65 & .875 \\
\hline 5 & Reading notices, schedules & 9 & 45.0 & 6 & 30.0 & 5 & 25.0 & 0 & 0.0 & 0 & 0.0 & 4.20 & .834 \\
\hline 6 & Reading e-mails & 12 & 60.0 & 7 & 35.0 & 1 & 5.0 & 0 & 0.0 & 0 & 0.0 & 4.55 & .605 \\
\hline & & & & & & & 1. & & 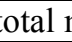 & & ore & 3.70 & 0.91 \\
\hline
\end{tabular}

Table 4.2 is concerned with reading activities which were frequently employed by observers and staff officers when they were discharging their duties and responsibilities in the mission areas.

On the basis of the information in the table, $60 \%$ of the observers and staff officers replied that reading emails was the most frequently needed reading activity. The second one was reading notices, schedules that are $45 \%$. Further, the next most frequent activities were reading reports and reading rules and regulations of UN and AU in which they took $20 \%$ each. Among the reading activities mentioned in it, reading articles, newspapers, magazines, journals on police and social topics $(15 \%)$ and reading manuals /statements $(10 \%)$ took their order third and fourth. On the other moment, the respondents said that reading reports (50\%) and reading e-mails (35\%) again were the frequently needed reading activities respectively.

Therefore, from this context, it is possible to say that reading e-mails is the crucial activity that the observers and staff officers carried out on times of their major duties and responsibilities while in the mission areas. The other point is reading notices; schedules could be the second most needed activity that the law enforcers worked out.

The mean values for the first two most frequently needed reading activities based on the responses of observers and staff officers were 4.55 and 4.2 respectively. This shows that the mean values are between four and five. Hence, the central tendency of the data denotes that the activities were frequently employed. The standard deviation values corresponding to the mean values were 0.65 and 0.834 . This implies that the first two most frequently needed reading activities are very important to carry out the activities in the mission areas.

Furthermore, apart from the mean and standard deviation, the total grand mean was 3.7 and the total standard deviation was 0.91 as shown in the table. Therefore, the whole reading activities are needed for the observers and staff officers in the mission areas as it has been mentioned above and the deviation also fit to the mean that is less than one. 
Table 4.3 Responses of Observers and Staff officers regarding to the English Language Needs (writing)

\begin{tabular}{|c|c|c|c|c|c|c|c|c|c|c|c|c|c|}
\hline \multirow[t]{3}{*}{ No } & \multirow[t]{3}{*}{ Writing activities } & \multicolumn{12}{|c|}{ Response } \\
\hline & & \multicolumn{2}{|c|}{ Always } & \multicolumn{2}{|c|}{ Usually } & \multicolumn{2}{|c|}{ Sometimes } & \multicolumn{2}{|c|}{ Rarely } & \multicolumn{2}{|c|}{ Never } & \multirow[t]{2}{*}{ Mean } & \multirow[t]{2}{*}{$\mathrm{SD}$} \\
\hline & & $\mathrm{F}$ & $\%$ & $\mathrm{~F}$ & $\%$ & $\mathrm{~F}$ & $\%$ & $\mathrm{~F}$ & $\%$ & $\mathrm{~F}$ & $\%$ & & \\
\hline 1 & $\begin{array}{l}\text { Writing reports } \\
\text { (incidents, performance } \\
\text { progress reports) }\end{array}$ & 8 & 40.0 & 7 & 35.0 & 3 & 15.0 & 1 & 5.0 & 1 & 5.0 & 4.00 & 1.12 \\
\hline 2 & $\begin{array}{l}\text { Writing daily occurrence } \\
\text { report }\end{array}$ & 13 & 65.0 & 6 & 30.0 & 1 & 5.0 & 0 & 0.0 & 0 & 0.0 & 4.60 & 0.60 \\
\hline 3 & Writing patrol report & 2 & 10.0 & 4 & 20.0 & 10 & 50.0 & 4 & 20.0 & 0 & 0.0 & 3.20 & 0.89 \\
\hline 4 & Writing shift log & 12 & 60.0 & 6 & 30.0 & 2 & 10.0 & 0 & 0.0 & 0 & 0.0 & 4.50 & 0.69 \\
\hline 5 & Writing scene of crime & 3 & 15.0 & 5 & 25.0 & 10 & 50.0 & 1 & 5.0 & 1 & 5.0 & 3.40 & 0.99 \\
\hline 6 & $\begin{array}{l}\text { Writing investigation } \\
\text { report }\end{array}$ & 2 & 10.0 & 6 & 30.0 & 9 & 45.0 & 2 & 10.0 & 1 & 5.0 & 3.30 & 0.98 \\
\hline 7 & $\begin{array}{l}\text { Writing information for } \\
\text { detention }\end{array}$ & 0 & 0.0 & 2 & 10.0 & 6 & 30.0 & 7 & 35.0 & 5 & 25.0 & 2.25 & 0.97 \\
\hline & & & & & & & iting & & tal & 0 & core & 3.61 & 0.81 \\
\hline
\end{tabular}

As it is indicated in the above table of 4.3 , for item $2,(65 \%)$ of the respondents agreed that the most frequently needed activity was writing daily occurrence report. According to the responses of observers and staff officers, writing daily occurrence report is a routine activity in the mission areas especially for police to do duties very well. The next most frequently needed activity was writing shift log which accounts for $60 \%$. When the observers and staff officers are on duty, they are expected to carry out their work critically. But when they become off duty, they should write a report that is shift log on which the other tries to do the activity based on that. Therefore, writing shift $\log$ is also most important in the mission areas.

Mean while, the following writing activities like writing reports (incidents, performance progress reports) $(40 \%)$, writing scene of crime (15\%), and writing patrol report $(10 \%)$ took the order how often the activities are needed in the mission areas. And from this result, we can say that writing reports like incidents, performance progress reports are also the most frequently needed activity practiced in the mission areas by observers and staff officers.

The mean values for the first most frequently needed writing activities were 4.6, 4.5 and 4 respectively. Thus, the central tendency according to mean result is high frequency. The corresponding standard deviation values were 0.6, 0.69 and 1.12. They are almost less than one. Therefore, it is possible to conclude that all the first three most needed frequently writing activities mean values and standard deviation fit each other. Since the mean values of these writing activities were more than 4 , it can be said that the tendency is inclined to usually needed. It denotes that how much all the preceding three activities were very necessary in the mission areas.

In general, there are about seven writing activities mentioned in this table. And the total mean score it is 3.61. Thus, it is possible to say that all those writing activities were highly needed and the standard deviation showed as less than one (0.8). Therefore, it doesn't deviate from the total mean.

Table 4.4 Responses of Observers and Staff Officers regarding to the English Language Needs (speaking)

\begin{tabular}{|c|c|c|c|c|c|c|c|c|c|c|c|c|c|}
\hline \multirow[t]{3}{*}{ No } & \multirow[t]{3}{*}{ Speaking activities } & \multicolumn{12}{|c|}{ Response } \\
\hline & & \multicolumn{2}{|c|}{ Always } & \multicolumn{2}{|c|}{ Usually } & \multicolumn{2}{|c|}{ Sometimes } & \multicolumn{2}{|c|}{ Rarely } & \multicolumn{2}{|c|}{ Never } & \multirow[t]{2}{*}{ Mean } & \multirow[t]{2}{*}{$\mathrm{SD}$} \\
\hline & & $\mathrm{F}$ & $\%$ & $\mathrm{~F}$ & $\%$ & $\mathrm{~F}$ & $\%$ & $\mathrm{~F}$ & $\%$ & $\mathrm{~F}$ & $\%$ & & \\
\hline 1 & Speaking during meetings & 3 & 15.0 & 5 & 25.0 & 8 & 40.0 & 3 & 15.0 & 1 & 5.0 & 3.30 & 1.08 \\
\hline 2 & $\begin{array}{l}\text { Giving briefings on } \\
\text { various topics }\end{array}$ & 3 & 15.0 & 5 & 25.0 & 7 & 35.0 & 3 & 15.0 & 2 & 10.0 & 3.20 & 1.20 \\
\hline 3 & Presenting oral report & 7 & 35.0 & 8 & 40.0 & 4 & 20.0 & 1 & 5.0 & 0 & 0.0 & 4.05 & 0.89 \\
\hline 4 & $\begin{array}{l}\text { Expressing views about } \\
\text { social and police's topics }\end{array}$ & 4 & 20.0 & 9 & 45.0 & 4 & 20.0 & 2 & 10.0 & 1 & 5.0 & 3.65 & 1.09 \\
\hline 5 & Speaking on the telephone & 13 & 65.0 & 6 & 30.0 & 1 & 5.0 & 0 & 0.0 & 0 & 0.0 & 4.60 & 0.60 \\
\hline 6 & $\begin{array}{l}\text { Sending messages on the } \\
\text { radio }\end{array}$ & 6 & 30.0 & 9 & 45.0 & 3 & 15.0 & 2 & 10.0 & 0 & 0.0 & 3.95 & 0.94 \\
\hline \multirow[t]{2}{*}{7} & $\begin{array}{l}\text { Giving comments, } \\
\text { suggestions and opinion } \\
\text { on different issues }\end{array}$ & 3 & 15.0 & 5 & 25.0 & 8 & 40.0 & 3 & 15.0 & 1 & 5.0 & 3.30 & 1.08 \\
\hline & \multicolumn{11}{|c|}{ Speaking skill total mean score } & 3.7 & 0.93 \\
\hline
\end{tabular}

Table 4.4 shows the frequency level of some speaking activities. According to this table, the most frequently needed speaking activity was speaking on the telephone. This activity was favored by $65 \%$ of the observers and staff officers. Besides, $35 \%$ of them replied that presenting oral report was the second most frequently needed 
speaking activity. These activities were followed by sending messages on the radio (30\%), expressing views about social and police's topics $(20 \%)$, speaking during meetings $(15 \%)$, giving briefings on various topics (15\%) and giving comments, suggestions and opinion on different issues also $(15 \%)$.

In addition, from the above data findings, there can be conclusion to describe in more precise ways. Therefore, the most needed speaking activity as it was mentioned above was speaking on the telephone. Actually, the respondents are police officers so they are expected to speak and communicate efficiently with their colleagues in the office. Moreover, since these staff officers and observers are given different office duties, they had to present the oral reports in the forms of effective communication and sending messages on the radio was also another necessary need of speaking activity in the mission area.

The mean values for the data gathered from the observers and staff officers with regard to the first three most frequently needed speaking activities were 4.6, 4.05 and 3.95. Therefore, it can be said that all the three mean values showed that how much these activities are frequently needed. In addition, the three consecutive standard deviations are $0.94,0.84$ and 0.60 . Therefore, it can be said that all the three standard deviations are less than one. This showed that it did not have any deviation from the mean.

By the same token, the whole seven speaking activities total mean and standard deviation is 3.72 and 0.93 , respectively. Therefore, since the total mean is more than 3.5, it can be said that all these speaking activities are necessary and appropriate to carry out the given duties in the mission areas.

\subsubsection{Analysis of Observers and Staff Officers' English Language Difficulties}

Almost all macro English skills which are believed to be important in order to discharge the duties and responsibilities of observers and staff officers in the UN peacekeeping mission areas are important. Thus, different on each skills were identified and presented to the sample respondents so as to indicate their level of difficulties on the four Basic English language skill areas. Therefore, the respondents have been given opportunities to rate the scales worded as" very great difficulty', 'great difficulty,' 'some difficulty,' 'little difficulty' and 'no difficulty,' As a result, the responses are summarized and described thoroughly in the tables below.

Table 4.5 Responses of Observers and Staff Officers on Difficulties they face in Different Listening Activities

\begin{tabular}{|c|c|c|c|c|c|c|c|c|c|c|c|c|c|}
\hline \multirow[t]{3}{*}{ No } & \multirow[t]{3}{*}{ Listening activities } & \multicolumn{12}{|c|}{ Response } \\
\hline & & \multicolumn{2}{|c|}{$\begin{array}{l}\text { Very great } \\
\text { difficulty }\end{array}$} & \multicolumn{2}{|c|}{$\begin{array}{c}\text { Great } \\
\text { difficulty }\end{array}$} & \multicolumn{2}{|c|}{$\begin{array}{c}\text { Some } \\
\text { difficulty }\end{array}$} & \multicolumn{2}{|c|}{$\begin{array}{c}\text { Little } \\
\text { difficulty }\end{array}$} & \multicolumn{2}{|c|}{$\begin{array}{c}\text { No } \\
\text { difficulty }\end{array}$} & \multirow[t]{2}{*}{ Mean } & \multirow[t]{2}{*}{ SD } \\
\hline & & $\mathrm{F}$ & $\%$ & $\mathrm{~F}$ & $\%$ & $\mathrm{~F}$ & $\%$ & $\mathrm{~F}$ & $\%$ & $\mathrm{~F}$ & $\%$ & & \\
\hline 1 & $\begin{array}{l}\text { Listening to the local } \\
\text { communities }\end{array}$ & 2 & 10.0 & 3 & 15.0 & 3 & 15.0 & 10 & 50.0 & 2 & 10.0 & 2.65 & 1.18 \\
\hline 2 & $\begin{array}{l}\text { Listening to the foreign } \\
\text { contingents }\end{array}$ & 3 & 15.0 & 9 & 45.0 & 6 & 30.0 & 2 & 10.0 & 0 & 0.0 & 3.65 & 0.88 \\
\hline 3 & $\begin{array}{l}\text { Listening to briefings, } \\
\text { discussions, meetings }\end{array}$ & 4 & 20.0 & 10 & 50.0 & 4 & 20.0 & 1 & 5.0 & 1 & 5.0 & 3.75 & 1.02 \\
\hline 4 & $\begin{array}{l}\text { Listening to radio } \\
\text { communications }\end{array}$ & 1 & 5.0 & 2 & 10.0 & 3 & 15.0 & 12 & 60.0 & 2 & 10.0 & 2.40 & 0.99 \\
\hline 5 & $\begin{array}{l}\text { Listening to video } \\
\text { /films/TV/ radio } \\
\text { channels }\end{array}$ & 6 & 30.0 & 10 & 50.0 & 3 & 15.0 & 1 & 5.0 & 0 & 0.0 & 4.05 & 0.83 \\
\hline 6 & $\begin{array}{l}\text { Listening to meetings, } \\
\text { seminars, conference } \\
\text { and workshops }\end{array}$ & 5 & 25.0 & 10 & 50.0 & 2 & 10.0 & 2 & 10.0 & 1 & 5.0 & 3.80 & 1.11 \\
\hline & & & & & & & 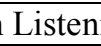 & & & & & 3.38 & 0.92 \\
\hline
\end{tabular}

According to the data given in table 4.5 as most of the respondents said that in all the listening activities that did have difficulties though level of difficulty they face varied. Thus, the three listening activities: listening to briefings, discussions, meetings, listening to videos /films/ radio channels, and listening to meetings, seminars, conference and workshops do have the same values of level of difficulties (50\%) which is great difficulty. Besides, $45 \%$ of them replied that listening to the foreign contingents was the second great difficulty of English language listening activity. And it was followed by listening to the local communities $(15 \%)$, and listening to radio communications $(10 \%)$.

On the other hand, as the respondents replied, the very great difficult activity was listening to videos /films/ TV and radio channels. It was noted by $30 \%$ of the observers and staff officers. Furthermore, the next very great difficulty of listening activity was listening to meetings, seminars, conference and workshop that were reported to be very great difficulty by $25 \%$. It was followed by listening to briefings, discussion and meetings (20\%), listening to the local communities $(10 \%)$ and listening to radio communications $(5 \%)$.

Therefore, is can be said staff officers and observers had difficulties in most of the listening activity. As they realized and observed in the mission areas, they said that listening activities were difficult comparing with reading 
activities.

Mean while, the mean values of the first three listening activities were more than three. For example, listening to video/films /TV and radio channels was 4.05, listening to meetings, was 3.75 , so this shows that how much these activities were difficult for observers and staff officers in the mission areas to carry out the duties and responsibilities.

The standard deviation denotes that there is a difference in the result of standard deviation which is $0.83,1.02$ and1.11 respectively in order of the three activities. It can be said that these activities were more or less not deviated from the mean. Although there is a difference in deviation from the mean, it is very obvious that the stated activities were among the great difficulty for the observers and staff officers.

However, as it has been seen the total mean or grand means and total standard deviation, the level of difficulty was appropriate. The grand mean and total standard deviation were 3.38 and 0.92 respectively. Therefore, it is possible to say that all the listening activities mentioned were difficult for the observers and staff officers.

In addition to this, they also recommended that listening to video/films/TV and radio channels were very great difficulty as well as listening to briefings, discussions and meetings. Thus, they claimed that they did not feel confident while they listened to foreigners especially if the speaker is native speakers. As they stated in the interview, the accent and pronunciation of the speakers posed problems to listen and respond accordingly. In general, to alleviate the listening problems of Ethiopian officers and observers, they said that they had to practice more and more in the language laboratory before the deployment and got the exposure with the native speakers.

Table 4.6 Responses of Observers and Staff Officers on difficulties they face in different Reading Activities

\begin{tabular}{|c|c|c|c|c|c|c|c|c|c|c|c|c|c|}
\hline \multirow[t]{3}{*}{ No } & \multirow[t]{3}{*}{ Reading activities } & \multicolumn{12}{|c|}{ Response } \\
\hline & & \multicolumn{2}{|c|}{$\begin{array}{c}\text { Very } \\
\text { great } \\
\text { difficulty } \\
\end{array}$} & \multicolumn{2}{|c|}{$\begin{array}{c}\text { Great } \\
\text { difficulty }\end{array}$} & \multicolumn{2}{|c|}{$\begin{array}{c}\text { Some } \\
\text { difficulty }\end{array}$} & \multicolumn{2}{|c|}{$\begin{array}{c}\text { Little } \\
\text { difficulty }\end{array}$} & \multicolumn{2}{|c|}{$\begin{array}{c}\text { No } \\
\text { difficulty }\end{array}$} & \multirow[t]{2}{*}{ Mean } & \multirow[t]{2}{*}{ SD } \\
\hline & & $\mathrm{F}$ & $\%$ & $F$ & $\%$ & $\mathrm{~F}$ & $\%$ & $F$ & $\%$ & $\mathrm{~F}$ & $\%$ & & \\
\hline 1 & $\begin{array}{l}\text { Reading magazines, } \\
\text { articles, news papers, } \\
\text { journals on police and } \\
\text { military of social topics }\end{array}$ & 2 & 10.0 & 4 & 20.0 & 10 & 50.0 & 3 & 15.0 & 1 & 5.0 & 3.15 & 0.99 \\
\hline 2 & $\begin{array}{l}\text { Reading letters, } \\
\text { memos, office } \\
\text { regulations, UN/AN rules } \\
\text { and policies reports }\end{array}$ & 2 & 10.0 & 3 & 15.0 & 7 & 35.0 & 5 & 25.0 & 3 & 15.0 & 2.80 & 1.20 \\
\hline 3 & $\begin{array}{l}\text { Reading } \\
\text { manuals/directives }\end{array}$ & 3 & 15.0 & 4 & 20.0 & 8 & 40.0 & 3 & 15.0 & 2 & 10.0 & 3.15 & 1.18 \\
\hline 4 & $\begin{array}{l}\text { Reading notices, } \\
\text { schedules }\end{array}$ & 1 & 5.0 & 2 & 10.0 & 3 & 15.0 & 9 & 45.0 & 5 & 25.0 & 2.25 & 1.12 \\
\hline 5 & Reading e-mails & 1 & 5.0 & 1 & 5.0 & 3 & 15.0 & 9 & 45.0 & 6 & 30.0 & 2.10 & 1.07 \\
\hline 6 & $\begin{array}{l}\text { Reading messages on the } \\
\text { internet }\end{array}$ & 2 & 10.0 & 3 & 15.0 & 11 & 55.0 & 3 & 15.0 & 1 & 5.0 & 3.10 & 0.97 \\
\hline & & & & $\mathrm{V} C \mathrm{I}$ & if & & 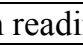 & & tota & & score & 2.76 & 1.04 \\
\hline
\end{tabular}

Table 4.6 revealed that the level of difficulty in the reading activities. According the observers and staff officers' reply, they said that in most of the reading activities they did not have much difficulty level values since the activities are easier comparing to other English language skills like listening, speaking and writing.

On the basis of the above table, $50 \%$ of the observers and staff officers replied that reading magazines, articles, newspapers, journals on police and military of social topics had some difficulty. And $20 \%$ of respondents also replied that this above mentioned reading activity they had great difficulty, but $10 \%$ of respondents said that they had very great difficulty. In connection with this, $40 \%$ of respondents replied reading manuals /directives they did have also some difficulty. But $15 \%$ and $20 \%$ of respondents said that in this reading activity they had very great difficulty and great difficulty, respectively.

On the other hand, reading notices and schedules and reading 45\% e-mails (45\%) were in the same level of difficulty that is little difficulty. But in the relative manner, reading manuals and directives (15\%) had a very great difficulty. It was followed by reading magazines, articles, news papers, journals on police and military of social topics and reading letters, memos, office regulations and UN/AU rules and polices reports with the same percentage $(10 \%)$.

To sum up, most of the reading activities which are carried out in the mission areas are not as such difficult activities. They can read and simply understand the written materials because all of the materials are prepared in a simple way to be understood by all the deployed troops. Therefore, the observers and staff officers did not face that much problem on reading activities in the mission areas. 
The mean values for the first three reading activities in some difficulty level were $3.15,3.15$ and 2.8 . This shows that all the reading activities mentioned in the table were fewer than 3.5. Thus, the central tendency denotes that the activities were not inclined to very great difficulty as well as great difficulty. Similarly, the standard deviation values corresponding to the mean values were $0.99,1.18$ and 1.2 . It means that all are almost more than one and this situation implied that there is deviation from the mean. Therefore, it can be said that from the other English language skills, reading is not very difficult for the observers and staff officers. To strengthen this idea, it is better to see the total mean and total standard deviation. Thus, the total mean and standard deviation of the reading activities were 2.76 and 1.04 respectively.

Table 4.7 Responses of Observers and Staff Officers on Difficulties They Face in Different Speaking Activities

\begin{tabular}{|c|c|c|c|c|c|c|c|c|c|c|c|c|c|}
\hline \multirow[t]{3}{*}{ No } & \multirow[t]{3}{*}{ Speaking activities } & \multicolumn{12}{|c|}{ Response } \\
\hline & & \multicolumn{2}{|c|}{$\begin{array}{c}\text { Very } \\
\text { great } \\
\text { difficulty }\end{array}$} & \multicolumn{2}{|c|}{$\begin{array}{c}\text { Great } \\
\text { difficulty }\end{array}$} & \multicolumn{2}{|c|}{$\begin{array}{c}\text { Some } \\
\text { difficulty }\end{array}$} & \multicolumn{2}{|c|}{$\begin{array}{c}\text { Little } \\
\text { difficulty }\end{array}$} & \multicolumn{2}{|c|}{$\begin{array}{c}\text { No } \\
\text { difficulty }\end{array}$} & \multirow[t]{2}{*}{ Mean } & \multirow[t]{2}{*}{$\mathrm{SD}$} \\
\hline & & $\mathrm{F}$ & $\%$ & $\mathrm{~F}$ & $\%$ & $\mathrm{~F}$ & $\%$ & $\mathrm{~F}$ & $\%$ & $\mathrm{~F}$ & $\%$ & & \\
\hline 1 & Presenting oral report & 5 & 25.0 & 10 & 50.0 & 3 & 15.0 & 2 & 10.0 & 0 & 0.0 & 3.90 & 0.91 \\
\hline 2 & Giving briefings & 4 & 20.0 & 11 & 55.0 & 3 & 15.0 & 2 & 10.0 & 0 & 0.0 & 3.85 & 0.88 \\
\hline 3 & $\begin{array}{l}\text { Asking and answering } \\
\text { questions during meetings, } \\
\text { shopping discussions in post } \\
\text { exchange }\end{array}$ & 3 & 15.0 & 4 & 20.0 & 9 & 45.0 & 3 & 15.0 & 1 & 5.0 & 3.25 & 1.07 \\
\hline 4 & Giving the press conference & 7 & 35.0 & 8 & 40.0 & 3 & 15.0 & 2 & 10.0 & 0 & 0.0 & 4.00 & 0.97 \\
\hline 5 & $\begin{array}{l}\text { Communicating with the } \\
\text { local communities and with } \\
\text { their police personnel } \\
\text { colleagues }\end{array}$ & 4 & 20.0 & 6 & 30.0 & 5 & 25.0 & 3 & 15.0 & 2 & 10.0 & 3.35 & 1.27 \\
\hline & & & Lev & 010 & fficult & & $\mathrm{ak}$ & ת & ta & Heal & ore & 3.67 & 0.95 \\
\hline
\end{tabular}

Table 4.7 depicted that issues related to speaking activities regarding to level of difficulties. The data on the above table shows that $55 \%$ of respondents replied that in giving briefings they had great difficulty. In like manner, the staff officers and observers put presenting oral report $(50 \%)$ in the second difficult place. They put giving the press conference in third place and it was chosen by $40 \%$ as having great difficulty. Therefore, the next great difficult activities were communicating with the local communities and with their police personnel colleagues $(30 \%)$ and asking and answering questions during meeting, shopping discussions in Post Exchange (20\%). Thus, it can be said that in the first three mentioned speaking activities they did have great difficulty for the observers and staff officers while they carried out their duties and responsibilities of speaking activities in the mission areas.

However, the respondents replied that there are also some speaking activities which are in a very great difficulty positions. The observers and staff officers believed that the very great difficulty speaking activity was giving press conference. It was supported by $35 \%$. The second one was presenting oral report which accounts for $25 \%$ relatively difficult compared with the other activities. They were followed by giving briefings $(20 \%)$ and with the same value communicating with the local communities and with their police personnel colleagues $(20 \%)$ and asking and answering questions during meetings, shopping discussions in Post Exchange (15\%).

As it is stated in the above table, the mean values of these speaking activities especially giving the press conference, presenting oral report and giving briefings were 4.00 and 3.90 and 3.85 respectively. Therefore, this data denotes that the central tendency is inclined to high difficulty. Therefore, the mean value data were more than 3.5 and this circumstance shows that all these speaking activities were difficulty for observers and staff officers to perform them in the mission areas. In addition to this, the standard deviation for giving press conference, presenting oral report and giving briefings are $0.97,0.91$ and 0.88 . This shows that this three speaking activities did not deviate from the mean values as a whole. Therefore, it showed that the level of difficulty is high.

In general, regarding to the total mean scores and total standard deviation of all these speaking activities, it is possible to say that their level of difficulty is comparatively high. The total grand mean was 3.67 and total standard deviation was 0.95 . Taking these points into account, we can consider and understand that speaking activities were very difficult to perform in the mission areas for Ethiopian observers and staff officer 
Table 4.8 Responses of Observers and Staff Officers on Difficulties they face in Different Writing Activities

\begin{tabular}{|c|c|c|c|c|c|c|c|c|c|c|c|c|c|}
\hline \multirow[t]{3}{*}{ No } & \multirow[t]{3}{*}{ Writing activities } & \multicolumn{12}{|c|}{ Response } \\
\hline & & \multicolumn{2}{|c|}{$\begin{array}{l}\text { Very great } \\
\text { difficulty }\end{array}$} & \multicolumn{2}{|c|}{$\begin{array}{c}\text { Great } \\
\text { difficulty }\end{array}$} & \multicolumn{2}{|c|}{$\begin{array}{c}\text { Some } \\
\text { difficulty }\end{array}$} & \multicolumn{2}{|c|}{$\begin{array}{c}\text { Little } \\
\text { difficulty }\end{array}$} & \multicolumn{2}{|c|}{$\begin{array}{c}\text { No } \\
\text { difficulty }\end{array}$} & \multirow[t]{2}{*}{ Mean } & \multirow[t]{2}{*}{ SD } \\
\hline & & $\mathrm{F}$ & $\%$ & $\mathrm{~F}$ & $\%$ & $\mathrm{~F}$ & $\%$ & $\mathrm{~F}$ & $\%$ & $\mathrm{~F}$ & $\%$ & & \\
\hline 1 & $\begin{array}{l}\text { Writing reports } \\
\text { (incidents, performance } \\
\text { progress reports) }\end{array}$ & 3 & 15.0 & 6 & 30.0 & 8 & 40.0 & 2 & 10.0 & 1 & 5.0 & 3.40 & 1.05 \\
\hline 2 & $\begin{array}{l}\text { Writing daily } \\
\text { occurrence report }\end{array}$ & 2 & 10.0 & 2 & 10.0 & 4 & 20.0 & 9 & 45.0 & 3 & 15.0 & 2.55 & 1.19 \\
\hline 3 & Writing patrol report & 4 & 20.0 & 7 & 35.0 & 5 & 25.0 & 3 & 15.0 & 1 & 5.0 & 3.50 & 1.15 \\
\hline 4 & Writing shift log & 1 & 5.0 & 2 & 10.0 & 3 & 15.0 & 8 & 40.0 & 6 & 30.0 & 2.20 & 1.15 \\
\hline 5 & Writing scene of crime & 4 & 20.0 & 7 & 35.0 & 5 & 25.0 & 3 & 15.0 & 1 & 5.0 & 3.50 & 1.15 \\
\hline 6 & $\begin{array}{l}\text { Writing investigation } \\
\text { report }\end{array}$ & 5 & 25.0 & 8 & 40.0 & 4 & 20.0 & 2 & 10.0 & 1 & 5.0 & 3.70 & 1.13 \\
\hline \multirow[t]{2}{*}{7} & $\begin{array}{l}\text { Writing information for } \\
\text { detention }\end{array}$ & 3 & 15.0 & 5 & 25.0 & 6 & 30.0 & 4 & 20.0 & 2 & 10.0 & 3.15 & 1.23 \\
\hline & \multicolumn{11}{|c|}{ Level of difficulty in writing skill total mean score } & 3.14 & 1.06 \\
\hline
\end{tabular}

As can be seen from table 4.8 , most of the respondents agreed that there were no very great difficulties they faced in writing activities in the mission areas. On the basis of the given information, $25 \%$ of respondents replied that writing investigation report had a very great difficulty level. The following activities were writing scene of crime $(20 \%)$, writing patrol report $(20 \%)$ and writing reports (incidents, performance progress reports which were $(15 \%)$. Therefore, we can say that all the listed writing activities in the table were not that much in very great difficult level while performing various tasks in the mission areas.

Similarly, $40 \%$ of the observers and staff officers replied that writing investigation report had great difficulty level. It was followed by writing scene of crime (35\%), writing patrol report (35\%) and writing report (incidents, performance progress reports) which was $30 \%$. Therefore, it can be said that these three writing activities are more lied on great difficulty level. Furthermore, most of the respondents replied that most of the writing activities did have little difficulties such as writing daily occurrence report was favored by $45 \%$, and writing shift $\log$ was $40 \%$. Since the observers and staff officers are expected to write different and various tasks in English, most of the writing tasks were not that much highly difficult in the mission areas to accomplish their duties and responsibilities.

More or less the mean values for the first four great difficulty writing activities based on the responses of staff officers and observers were 3.7, 3.5, 3.4 and 3.5 with nearly the same value. They are more than three. Therefore, they are also more or less nearer to four which designates moderately performed activities. Their standard deviation values were $1.13,1.15,1.05$, and 1.15 . They are more scattered from the mean in comparison with the values of the responses given by observers and the staff officers. Because of this, it is better to say that all writing activities deviated from the mean value which is different in context from person to person.

With the same regard, the total mean score and total standard deviation showed that they are moderate. They are 3.14 and 1.06 respectively. Thus, all the writing activities mentioned on the above table depicted that they were necessary in the mission areas to perform different tasks. By considering the scores of total mean and standard deviation we can conclude that the level of difficulty was not that much challenging. All are in total moderate.

\subsection{Analysis of the Interview}

The interview items supplement the findings of the questionnaire more information about the observers and staff officers' English language need assessment. In this section, the responses' of the interviewees were analyzed and interpreted qualitatively in thematic way to cross check with the questionnaire.

As described in chapter three, a semi-structured interview took place with eight observers and staff officers to assess the needs of their English language skills and sub-skills. Thus the data gathered through the interview has shown consistent results with the findings of the questionnaire. In order to achieve these goals, seven interview questions were presented below with their relevant probes as follow:

For each interview items, the interviewees respond independently and for these questions their own probes are described. The first interview question was meant to elicit about the English language skills level of difficulties in the mission areas. For example, the first interview question was "What English language skills problems you faced while you were carrying out the activities in the mission areas regarding to:

Listening

Reading

Writing

Speaking

Therefore, interviewee 1 replied about question 1 as follows:

I think listening to briefings, discussions, meetings, listening to videos/films and radio channels, and listening to 
foreign contingents were difficult activities in the mission areas. And from the reading activities, they were not that much difficult. However, presenting oral report, giving briefings and giving press conference are difficult from speaking activities. In addition to this, writing investigation report was a difficult activity in the mission area followed by writing scene of crime and writing patrol report respectively."

Interviewee 2 also gave his explanation the first question like this:

I faced English language problems in the mission areas. From listening language skill, I faced that listening to briefings discussions and listening to foreign contingents. Reading manuals or directives were difficult in the reading skills. And giving press conference and presenting oral report were difficult from speaking. I faced also problems from writing activities like writing investigation reports and writing patrol report as well.

In the like manner, interviewee 3 forwarded that:

As far as I am concerned, I had got English language skill problems in different sections. For example, I got the problems of listening meetings, seminars, conferences and workshops, listening to briefings, discussions and meetings. Reading skill activities couldn't be said that they are difficult. They are almost less difficult. I think the rest of two language skill activities are great difficulty like presenting oral repot, proving the briefings and giving press conference from the speaking skill activities and trying to write investigation report and scene of crime were great difficult from writing skill activities.

With the same manner, the rest of 5 interviewees replied for the first question as to the above 3 interviewees'. Therefore, it is possible to say that there are many English language skill problems that the interviewees faced during the time of carrying out the activities from the basic four English language skills and sub-skills.

The purpose of the second interview question was to put the level of English language skills according to their importance in the mission areas. For instances, the first question was 'Put the above English language skills according to their importance in the mission areas:

- listening writing

-reading speaking

Therefore, the interviewee 1 said that:

According to me, speaking, listening, writing and reading skills were put in order based on their importance.

Interviewee 2 also replied that as follow:

First, I understood that speaking had the great importance followed by writing and listening in the respective order in the mission areas. Most of the activities are important to carry out the activities'.

In addition, interviewee 3 said about question 2 as follows:

I can put the English language skill activities in order according to their importance in the mission areas. These are speaking, listening, writing and reading. All the language skill activities are important though they do have a critical order in terms of their degree.

All the interviewees positively perceived that that the English language skills: speaking, listening, writing and reading as their own order here are very important. Therefore, it can be concluded that the order of these English language skills did have a great role to accomplish any tasks based on their order primarily in the mission areas.

However, the purpose of the third question is different from the above two questions. It asked the English language skills level of difficulties especially in the mission areas. Therefore, almost all the interviewees replied that speaking, writing and listening activities should be given an intention as mentioned respectively. As it is known in common, the Ethiopian observes and staff officers are foreign language speaker of English. As a result, they did have speaking problems primarily and followed by writing and listening activities.

The main concern of the fourth question was to know the impact of observers and staff officers' English language skills weakness. Therefore, the question was 'What was the impact of weakness in English language?' With this regard, interviewee 1 replied as follows:

The first thing of observers and staff officers' English language weakness is the exposure to the language. There is no good environment to practice the skills very well.'

With the same manner, interviewee 2 replied that:

Most of observers and staff officers do have weakness in English language and the impact was not to get enough environment and training to improve and practice these four language skills.'

In general, all the respondents have the same consensuses on the fourth question. Since they didn't get opportunities to practice the English language skills, they did have already language weakness. As the observers and staff officers stated that environment, exposure and not getting enough training are the impacts for the weakness.

To sum up, most of the respondents (interviewees) disclosed that speaking activities were the most important one to accomplish duties in the mission areas. The following activities were writing, listening and last reading. On the other hand, to alleviate the language skill problems, solutions should be made like creating opportunities for the observers and staff officers to practice the skills more and more and let expose them to drill the language 
anywhere and language laboratory.

\subsection{Analysis of the English course book Material being in use}

An attempt was made to analyze the English language course book material (Campaign English for Law Enforcement) using an evaluation checklist developed by Cunning worth (1995) and Donovan and Little john in Tomlinson (1998) containing ten questions (see Appendix 3). The checklist was employed to evaluate whether or not the material satisfied adequately the English language needs of Amhara Police College peacekeeping English project trainees who will serve as observers and staff officers under the auspices of the UN/AU.

The first question in the checklist was whether the material was based on a careful analysis of the trainees' needs. The trainees' needs mainly refer to the occupational needs of observers and staff officers since most of them serve in the stated positions after they finish the course. When the material is evaluated in light of their needs, it is possible to say that it was designed based on the trainees' needs. The reasons for saying so are the following. First and foremost, the material is designed for the police. It has incorporated the rigorous language analysis of a good English for specific purposes course with the teach ability of a good general English course. It has dealt with real issues that concern servicemen and women. Second, it has encompassed topics and texts from a variety of international police contexts, including the US, the UK, NATO and the UN. Third, it has audio CD which enables trainees to listen to various people from different parts of the world. However, it has some shortcomings when we consider the need of African observers and staff officers in general and Ethiopian observers and staff officers in particular. One of its main shortcomings is it does not include topics related to Africa. It entirely focuses on Europe and America. Our observers and staff officers serve in Africa, so having knowledge about the African community has great advantage to cope with challenges and be successful in mission areas. For example, in the course book material at unit one 'Alpha' page eight talked about the American police woman and on page 12 at 'Delta' there are discussions on Italian and Finish police.

The second question was about whether the contents in the material appeal to the specific needs of trainees. Before answering this question, it is good to give some highlights about the specific needs of the trainees as wouldbe observers and staff officers. As observers and staff officers, the trainees will be expected to give and attend briefings, communicate with the local community as well as foreign contingents, read and write different kinds of reports, make and receive calls, participate in meetings and discussions, conduct interview, present oral report, socialize with commissioned and Non-commissioned officers (NCOs) from other countries, express views, give suggestions and comments on various issues, and the like. With regard to the aforementioned points, one can say that the material included most of them. Some of the contents clearly support the stated argument. This can be seen from the following contents of the material: reading and writing correspondence and reports, making and receiving calls, giving and attending briefings, socializing with officers and NCOs from other countries. Nevertheless, the contents are not covered in depth. Trainees need to practice a lot in order to satisfy their specific needs. The text is shallow though it covers the necessary areas. All the contents in the course book like police community support at page 24 , domestic abuse on page 37 and drug and alcohol on page 46 are necessary for observers and staff officers, but they are presented in a scanty way.

The third question asked whether the text helps the trainees to be equipped with the necessary skills and strategies that allow them to perform effectively in English language in professional situation. The material is designed to meet the English language needs of law enforcement officials personnel engaged in all operations including peacekeeping, humanitarian assistance and training exercises. Besides, the tasks pay attention to the macro skills as well as military terms and grammar. Thus, the text helps would be observers and staff officers to be effective and efficient in mission areas. However, it should be supported by other supplementary materials since it requires additional exercises to perform the tasks in the material properly. Moreover, it does not give sufficient opportunity to trainees to practice each activity in detail. Because all the ideas raised in the course book are important to carry out in the mission areas though it was not delivered in detailed way. For example, vehicle checks on page 18 , anti-behavior on page 22 and human traffics on page 88 .

The fourth question attempts to examine the relationship between the activities in the material and real life situations. The learning activities are related to what happens in the real world in many aspects. For example, there are activities about giving and attending briefings, making and receiving calls, making, accepting and declining invitations, giving advice on a military situation. We can find all these in real life situation. But the material lacks the inclusion of authentic materials which are directly related to the real world. For example, we don't find adequate excerpts from newspapers, articles, etc.

The fifth question is concerned with whether the learning activities have outcomes or products which will help trainees to evaluate their performance. The material presents new language items, gives trainees opportunity to practice the items, and let students use the language by themselves. The material has other components including a workbook. This workbook helps trainees evaluate themselves in relation to their performance.

The sixth question is designed to evaluate the material regarding the extent to which the material is organized and patterns of communicative interaction. The material presents different titles. Some of them are about the 
military and others are about humanitarian assistance, and media operations. Based on these topics, it presents various grammar items contextually. It deals with the form and use of these items. It also incorporates functional English. The material attempts to enhance communicative interaction. Most of the tasks are performed in pairs.

The seventh question was intended to assess what language skills were emphasized. The material presents the skills in an integrated manner. All the skills are not presented separately. They are interrelated. For example, reading texts lead to speaking, listening and writing. They also serve to present grammar in context.

The eighth question dealt with whether the material motivates learners by considering learners' psychological, social and cultural factors. In this regard, the material does not consider the stated issues. It is entirely about the western world. Almost in all aspects, it considers only European and American culture. It does not incorporate our learners' psychological, social and cultural factors. It deals with western dishes, leaders, and mentality. Thus, it needs to be improved in this aspect. Since Ethiopian observers and staff officers participate in Africa, they should have good understanding about African culture, mentality and society. This has its own impact on the success of peacekeeping mission.

The ninth question was about how the text deals with presentation, practice and production of grammar items. The grammar items are taken from texts. Thus the presentation is related to the text and the items are contextualized. The forms are presented followed by explanations about their uses. Then students practice the items. Finally, during the production stage, students are asked to use the items in speaking and writing. Yet, the amount of practice is not sufficient to enable students use the items appropriately when they speak and write.

The final question was about the presentation, practice and production of vocabulary appropriate to carry out duties and responsibilities in relation to trainees' professional needs. Most of the lexis's are related to the Law Enforcement profession. In most cases, the vocabulary items are presented in the form of matching. Definitions of the words are given and students are asked to match the words with their definition. It also presents the definitions of words and asks students to find the words from the text. It does not give sufficient opportunity to practice the vocabulary items. This affects the proper use of the words when it is necessary to use them. Students seem to understand the meaning and usage of the words. However, when they are tested, they may not understand what the words mean and how they are used.

\subsection{Discussion of the Findings}

The main concern of this study was to assess the English language needs of observers and staff officers in the mission areas. Thus, the findings of the analysis were integrated and discussed in this section. The discussions of the findings were made in relation to the research questions posed in chapter one to address the objectives of the research questions. The findings or results of the analysis gathered through different tools brought together and discussed as follow.

\subsubsection{Observers and Staff Officers' English Language Skills Need to Develop}

As indicated earlier, the first research question was aimed at to find out the English language skill needs of observers and staff officers to be developed in the mission areas. The overall findings indicated that all language skills are needed, but some of them are very needed to be developed so as to carry out duties and responsibilities. Similarly, as described from the result of the questionnaire and interview about the need of language skills, observers and staff officers disclosed that listening to instructions given by officers in charge of various tasks and listening to foreign contingents and local communities were the most important needed activities in the mission areas.

The findings of this study are in line with the results found in Girum (2014) which investigated the language skill needs of observers and staff officers of military on listening activities. As it was stated in his study, listening to local communities, contingents and listening to briefings on military topics and social issues were the most needed activities. There are some differences in variables between this research and Girum Fisha's. Thus, the basic difference is concentrating on Law Enforcement officials and Militaries respectively.

On the other hand, the result of reading activities showed that reading e-mails reading schedules and notices were the most frequently needed activities. With this regard, Girum (2014) findings' had also similar variables which are very needed in the mission areas by observers and staff officers to discharge their duties and responsibilities.

Furthermore, this study revealed that the most frequently needed speaking and writing activities in a clear way. Therefore, the study stated that writing different reports such as occurrence reports, shift logs, and incidents of performance progress reports were crucial in the mission area. Meanwhile, in Girum (2014) research work almost all writing skill activities were frequently needed to discharge the duties and responsibilities in the mission areas.

Similarly, the most important and most frequently needed speaking activities incorporated on speaking on telephone, presenting oral report expressing views about social topics, sending messages on the radio and giving briefings on various topics. These activities were an integral part of observers and staff officers' duties and responsibilities. Moreover, the interviewees elaborated that the importance and frequency level of the speaking 
activities differed from observers to observers and staff officers to staff officers based their assignments.

Finally, the interviewees also explained that the critical problem occurred in the mission area concerning to language is on speaking parts. As it I known, most of the peacekeepers are either the second language speaker of English or English is their mother tongue .But all the Ethiopian peacekeepers use English foreign language which has been practiced in the mission areas since it is an occupational language.

\subsubsection{Observers and Staff Officers' English Language Skills Level of Difficulties}

The second research question was aimed at identifying the observers and staff officers' English language skill level of difficulties carried out in the mission areas. Therefore, they reacted through the questionnaire and interview as well.

The results of observers and staff officers' response revealed that level of difficulties in the listening activities are listening to meetings seminars, conferences and workshops, listening to videos/ films/ TV/ radio channels. As compared to Girum (2014) findings, all the listening activities mentioned above are similar. Therefore, the only difference is listening to briefings, discussions and meetings to the side of their research study.

However, the reading activities' result of this study is in line with Girum (2014) findings. For example, the result of this study revealed that there are no most difficult reading activities like reading e- mails and reading manuals and directives. Those who participated in the interview stated that the observers and staff officers were expected to read various written materials to discharge their duties and responsibilities. But they said that most the reading activities were not very greatly difficult to understand. As they stated clearly, they could understand the whole reading materials since they can refer other reference materials like dictionary.

On the other hand, the result of study replied that speaking is somehow a challenging in time of communication with other deployed foreign contingents. Thus, the Ethiopian observers and staff officers faced problems of presenting oral report, giving briefings and giving press conference. With the same regard, Girum (2014) revealed that how most of the speaking activities were challenging for Ethiopian observers and staff officers since it is a foreign language. Therefore, there a great difference between Ethiopian troops and other foreign troops in speaking English in time of communication.

From the writing angles, the result obtained from the study showed that writing investigation report, writing scene of crime and writing patrol report were categorized under the position of difficulty level for observers and staff officers to carry out their duties and responsibilities in the mission areas. However, there are differences of writing activity results in Girum (2014) study. According to him, the most difficult writing activities were writing minutes and office memos. Actually, this happened because the duty they got is different since they are military and Law Enforcement officials.

\section{CHAPTER FIVE: Summary, Conclusion and Recommendation 5.1 Summary of the Findings}

As it is stated in the previous chapters of this work, the main objective of this study was to assess the English language needs of the staff officers and observers who had been deployed in the UN peacekeeping mission areas. These peacekeeping participants were police who have been working in different parts of Amhara police commission, in the zone police bureau and even in the police college. In order to achieve the objective, all data were gathered through the questionnaire, interview and text analysis. Therefore, the questionnaires were distributed for those observers and staff officers who served as peacekeeper in different parts of African countries and Haiti under the auspices of the UN. Moreover, the interview was also conducted with some of the interviewees so as to cross check whether it is related and similar to the questionnaire. On the other hand, the text book which is currently being in use was analyzed using a checklist developed by CunningsWorth (1995) and Donovan and Little John (1998).

Having been analyzed, the data gained from the questionnaire, interview and text analysis the following major points were found.

$>$ Most of the respondents' agreed that speaking, listening and writing are the most important skills which enable the observers and staff officers to accomplish their duties and responsibilities effectively. And all these Basic English language skills are highly needed in the mission areas for the sake achieving the tasks successfully.

$>$ Listening to instructions given by officers in charge of various tasks, listening to foreign contingents and local communities and listening to radio communication were the most frequently needed listening activities for observers and staff officers, and with the same sense listening to television /radio was to some extent needed.

$>$ When we consider the reading activities, reading e-mails, reading notices, schedules were the most needed reading activities in the mission areas to accomplish the day to day routines the staff officers and observers' duties and responsibilities. Moreover, reading reports and reading rules and regulations of the UN and AU were also the usually needed activities.

$>$ Writing daily occurrence report and writing shift log were the mostly needed writing activities by observers and staff officers to carry out their duties and responsibilities in the mission areas. In addition, writing reports like incidents, performance progress reports were also very frequently needed. 
$>$ Speaking on the telephone and presenting oral report were the most and much needed speaking activities for the observers and staff officers to communicate with their colleagues. In contrast, speaking during meetings, giving comments, suggestions and opinion on different issues and giving briefings on various topics were also relatively needed activities.

> Listening to videos / films/TV/ radio channels, listening to briefings, discussions, meetings and listening to the foreign contingents were the most difficult listening activities. Thus, for observers and staff officers, there had been other English language difficulties in the mission areas such as giving the press conference, giving briefings, presenting oral report, writing investigation report, writing scene of crime and writing the patrol report.

$>$ The text book entitled with campaign English for military from level 1 to 3 and law enforcement are designed to meet the English language needs of police personnel in all peacekeeping operations and humanitarian assistance as well. It has dealt with real issues that concern the police. Although these text books incorporated many topics and texts from a variety of global military and police contexts, it doesn't include many topics that encompass the African context and culture.

\subsection{Conclusions}

It has been indicated that the main purpose of this study was to assess the English language needs of staff officers and observers deployed in the UN mission areas. In general speaking, an attempt has been made to identify and priotorize the English language basic skills. Therefore, it can be concluded that speaking, listening and writing area the most important skills which enable the observers and staff officers to accomplish their duties and responsibilities successfully in the UN mission areas. And all these macro English language skills are highly needed so as to accomplish all activities what are expected in the mission areas.

In general, the following conclusions were made based on the findings of the study:

$\rightarrow$ Regarding to the listening activities, observers and staff officers need some activities predominantly like listening to instructions given by officers in charge of various tasks and listening to foreign contingents. Furthermore, they should have good reading skill in the stated areas to discharge their duties properly. The most needed reading activities which are very mandatory were reading e-mail and reading manuals and directives.

$\rightarrow$ Mean while, with regard to speaking and writing activities, the observers and staff officers are expected to speak and write different tasks which are achieved in different mission areas like speaking on the telephone, presenting oral report, writing daily occurrence report and writing shift log.

\subsection{Recommendations}

Depending on the results obtained from the study, there are various points that should be recommended. Having realized this, the researcher has suggested the following points as remedies.

$\rightarrow$ The Amhara police college peacekeeping English project should give priority to speaking, writing, listening and reading respectively in the time of training for the assigned police who are intended to be deployed the UN peacekeeping mission areas. They should get ample opportunities to practice the skills and make them proficient as well as tough enough in English language basic skills.

$\rightarrow$ There should be the actual relationship between the training given for the staff officers and observers and what is actually happening in the mission areas. Thus, there must have a plat form which invites the experienced observers and staff officers to share their experiences for other trainees. In other words, veterans should be invited to share and exchange their experience with the novices.

$\rightarrow$ The research has identified the most frequently needed English language activities carried in the mission areas. These activities are listening to instructions given by officers in charge of various tasks, listening to radio communication, reading e-mails, reading. Notices /schedules, writing shift log, writing daily occurrence report, speaking on the telephone and presenting oral report. Therefore, the training should give more emphasis for these identified activities to equip them and make them proficient to carry out the duties and responsibilities of observers and staff officers while they are deployed in the mission areas.

$\rightarrow$ The research has also identified the difficulty areas which hinder the observers and staff officers from discharging their duties and responsibilities. Participants had difficulties in listening to videos $/$ films $/ \mathrm{TV} / \mathrm{radio}$ channels, listening to foreign contingents, giving briefings, presenting oral report, giving press conference, writing investigation report, writing scene of crime and others should be considered to reduce the problem. So as tackle these problems, the trainees should be encouraged to use and practice their English language skills freely while in training situations. If we did this, they would develop confidence on their own language ability which helps for the mission areas to accomplish the duties and responsibilities efficiently.

$\rightarrow$ Although the text books were designed and prepared in good manner, there are some problems which are occurred in it. Thus, the text books should be supplemented by various topics; especially they should give attention and focus on African culture, society and psychology since the Ethiopian observers and staff officers 
have been participating in Africa. If some African topics are included, they will help them to realize more about Africa in general and particularly for the place where they are serving.

\section{References}

Abebe Mamo. (1997). Developing and Appropriate English Course for Technical Students. (An Unpublished MA Thesis). Addis Ababa: Addis Ababa University.

Abraham Menna. (1993). Developing Criteria for a Course in English Aircraft Technicians of the Ethiopian Air Force. (AN Unpublished MA Thesis). Addis Ababa: AAU.

Arnold, A. and Harmer, J. (1990). Advanced Writing Skills. Longman Group UK Limited.

Belachew Zerihun. (2008). English Language Needs Analysis of Construction trainees in Entoto Technical Vocational training college. (An Unpublished MA Thesis). Addis Ababa: Addis Ababa University.

Brindley, G.P. (1989). The Role of Needs Analysis in Adult ESL Program Design. In R.K. Johnson P. 36-38.

Byrne, D. (1995). Teaching Writing Skills. Longman Group UK Limited.

Clark, S.M. (2006). Campaign: English for the Military. Macmillan Publishers Limited.

Carver, D. (1983).Some Propositions about ESP. The ESP Journal, 2, 131- 137.

Cordasco, F. and Gatener, E. (1963). Research and Report Writing. Bareness and Noble, Inc.

Dudley- Evans, T. \& St John, M. (1998). Developments in ESP: A multi-disciplinary Approach. Cambridge: Cambridge University Press.

Evans, I.D. and St. John, MJ. (1998). Development in English for Specific Purposes. Cambridge University Press.

Fisha Abadi. (2004). Determining the English Language Needs of the Students of Agriculture. Mekele University Focus. (An Unpublished MA Thesis) AAU.

Girum Fiseha. (2014). Assessing the English Language Needs of Observers and Staff Officers: With Special Reference to Ethiopian Air Force Peacekeeping English Project. (An Unpublished MA Thesis). AAU.

Haile Kassahun. (2015). Determining the English language Needs of Law students' and designing English for Legal Academic purpose (ELAP) Syllabus. Addis Ababa: Addis Ababa University. ( An unpublished PHD dissertation).

Harmer, J. (2001). The Practice of English Language Teaching. Cambridge: CUP.

Hutchinson, T. and Waters, A. (2006). English for Specific Purposes. Cambridge University Press.

Jardan, R.R. (1997). English for Academic Purposes: A guide and Course Book for Teacher. United Kingdom: CUP.

Kennedy, C. and Balitho, R. (1984). English for Specific Purpose. London Macmillan.

Little Wood, W.T. (1981). Communicative Language Teaching. Cambridge.

Mackay, R and Mount ford, A. (1978). English for Specific Purposes. London: Longman.

Mohammed Seid Mohammed. (2007). Discovering the English Language Needs of Learner (cadets): the Cast of Ethiopian Police College. (An Unpublished MA Thesis). AAU.

Munby, J. (1978). Communicative Syllabus Design. Cambridge University Press.

Nunan, D. (1988). The Learner- Centered Curriculum: A study in Second Language Teaching. Cambridge University Press.

Richards, Jc. (2001). Curriculum Development. In Language Teaching. Cambridge University Press.

Robinson, P. (1980). ESP (English for Specific Purposes). Oxford: Pergman Press.

Strevens, P. (1977). Special Language Learning: a Perspective Language Teaching Linguistics, 10(3): 145-163.

Widdowson, H. G. (1983). Learning Purpose and Language Use Oxford: Oxford University Press. 